This is an author produced version of a paper published in Journal of Research in Marketing and Entrepreneurship. This paper has been peer-reviewed but may not include the final publisher proof-corrections or pagination.

Citation for the published paper:

Astner, H. and Gaddefors, J. (2021), "Identities at work in developing a new market", Journal of Research in Marketing and Entrepreneurship, Vol. 23 No. 1, pp. 1-23. https://doi.org/10.1108/JRME-07-2018-0038

Access to the published version may require journal subscription. Published with permission from: Emerald Publishing Limited under Creative Commons Attribution Non-commercial International Licence 4.0 (CC BY-NC 4.0). To view a copy of this license, visit http://creativecommons.org/licenses/by-nc/4.0/

This publication is openly available thru SLU publication database, http://urn.kb.se/resolve?urn=urn:nbn:se:slu:epsilon-p-109058 


\title{
Identities at Work in Developing a New Market
}

\author{
Hanna Astner and Johan Gaddefors \\ Department of Economics, Swedish University of Agricultural Sciences, Uppsala, Sweden
}

\begin{abstract}
Purpose: The purpose of this paper is to explore the role of identities in entrepreneurial processes during the development of a new market. Two research questions are employed: 1) How do the founder's identity, corporate identity and market identity interact as a new market is developing?, and 2) What are the functions of identity in the entrepreneurial process?
\end{abstract}

Design/methodology/approach: This qualitative research is grounded in multiple case studies including five start-ups in Sweden. Interviews were conducted with the founders at several points in time and accompanied by observations of websites, media performance, policy documents and commercial material. Analysis was conducted in an iterative process between empirics and theory.

Findings: The findings show how identities develop in entrepreneurs, firms and the market and how the interactions between these three levels of identity affect the development of each. We recognize and discuss three functions of identity: 1 ) a constructing function, in which identity is used to create a new firm and market, 2) a guiding function, which navigates between identities by imposing identity work on founders, firms and markets, and 3 ) a configuring function, which takes part in shaping contexts.

Originality/value: There is a vast amount of literature on the development of companies and markets, yet start-ups in new markets operate in different contexts and face different challenges that we know less about. This paper targets the latter and proposes identity as a useful lens for understanding the dynamics between entrepreneurs, start-ups and the new market.

Research limitations/Implications: This article opens a space for future research on identities to advance understandings of how new firms and markets are developed. Investigating identity shows the importance of context to entrepreneurial processes. This points towards a need for researching different contexts, but also to the potential limited value of our study.

Practical implications: The paper offers guidance to founders and managers in understanding and navigating different identities. Founders and managers are provided with a set of critical questions, which aim to assist when managing identity-related concerns.

Keywords: Context, Entrepreneurial process, Identity work, Marketing, Market identity, Corporate identity

Paper type: Research paper 


\section{Introduction}

The predominant literature in marketing is devoted to how to develop and sustain already existing corporations and markets, whereas less research has focused on how new firms and new markets are developed. However, start-ups in new markets face different challenges (Santos a Eisenhards, 2009). These challenges lie partly in the ambiguous environment constituted by a new market, in which customers are unclear, products are not well defined and value chains are not established (Santos and Eisenhardt, 2009). Other challenges lie in the newness of the firm, where conditions for start-ups differ substantially from the conditions that apply to established firms (Abimbola, 2001; Boyle, 2003; Rode and Vallaster, 2005; Abimbola and Vallaster, 2007; Petkova and Rindova, 2008; Bresciani and Eppler, 2010). Where an established firm can rely on former experiences, business networks and legitimacy, start-ups generally lack all those assets due to being new and unknown. Moreover, start-ups often "depend on the cooperation of strangers, have low levels of legitimacy, and are unable to compete effectively against established organizations" (Freeman, Carroll \& Hannan, 1983). Thus, establishing a new firm in a new developing market is a double challenge, as both the firm and the market lack structure due to the early stage of formation.

In developing entrepreneurs, firms and markets, the concept of identity has proven to be important, and identity has been approached on the individual, corporate and market levels. Starting with a founder's individual identity, this has been found to be constructed through social interactions and repeated selfreflection as founders engage in (amongst others) entrepreneurial activities (Lindgren \& Wåhlin, 2001). Regarding the corporate identity, this has been concerned with the organizational features that make a firm unique (cf. Balmer and Gray, 2003) and the intent for this identity to be translated to the market (cf. Abratt \& Kleyn, 2012). This has been recognized as a powerful tool to differentiate and build commitment amongst stakeholders (van Riel and Blamer, 1997; Maurya, Mishra, Anand \& Kumar, 2015), which is important for a firm's survival and success in a market (Abimbola \& Kocak, 2007), not least for start-ups (Petkova and Rindova, 2008; Bresciani and Eppler, 2010). Finally, market identity has been described as the common denominator in the market, which is collectively shared between market members (Navis \& Glynn, 2010). While there is literature that focuses on each of the different levels of identity, few studies have shown how these three levels (the founder, firm and market) interact with one another. There have been some attempts, such as Markwick and Fill (1997), who compare an individual's identity to a corporate identity. This reasoning is extended by Gioia, Schultz and Corley (2000), who suggest that there are similarities between the identity of an individual and the identity of an organization, as both are created in interaction with outsiders. Another example is Balmer (2008), who explains that individual identities can shape corporate identities. Navis and Glynn (2010) explain that just as market identity is collectively shared, it is collectively constructed as members emphasize similarities across firms. However, none of these contributions provide an integrated perspective of how identities develop that considers individuals, firms and markets. Exploring this could provide understandings of the entrepreneurial processes as new firms and markets are created and developed. It could thereby help founders to manage and navigate corporate identity. Thus, by combining concepts within marketing and entrepreneurship, this paper provides novel insight into how the identity of individuals, firms and markets interact to create new firms and new markets.

Our aim in this paper is to explore the role of identities in the entrepreneurial processes during the development of a new market. Two research questions are employed to guide this endeavour:

1) How do the founder's identity, corporate identity and market identity interact as a new market is developing?

2) What are the functions of identity in the entrepreneurial process? 
We focus on three contexts involved in the co-creation of firms and markets: the individual identity of the founder, corporate identity and market identity. This is done by following the development in five new, small firms within the meal-kit market in Sweden. This sector is especially interesting when it comes to the concept of identity, as choices concerning food today have become linked to individual identity, offering a form of self-expression and a way of asserting values. The five start-ups that we report on all entered the market at an early stage, focus on similar geographical areas and have comparable categories of customers and products. They were all trying to establish their new businesses and simultaneously they were, independently, but as a collective, establishing a new market.

This paper explains and aligns corporate identity with the individual identity of a founder and market identity. Our findings illustrate how identities at these three levels interacted as a new market developed, and thus how identities interacted with context. We also demonstrate the challenge involved in navigating between identities on different levels, and argue that contradicting identities lead to identity work by individuals and institutions. Founders and executive managers will be able to use this knowledge for guidance in making strategic decisions concerning corporate identity. Here, we provide a set of critical questions for founders and managers to reflect upon when navigating between levels of identity. Additionally, academics will be able to use these ideas as a basis for empirical research. In broad terms, we illustrate how the concept of identity allows us to discuss the interaction between entrepreneurship and context.

The next chapter provides an overview of the literature, followed by a discussion of our methods, a presentation of our findings, and a discussion. Finally, we present our conclusions and describe the contributions of the work.

\section{Conceptual framework}

\subsection{Entrepreneurship and context}

The development of firms and markets is central to entrepreneurship, where actors "take a chance in the hope of gain" (Penrose, 1995, 33). Entrepreneurship is historically treated as an individualized phenomenon allocated to 'the entrepreneur' acting in a presumed business environment (Bygrave and Hofer, 1991; Shane and Venkataraman, 2000; Watson, 2013). However, as entrepreneurs develop firms and markets, they bounce ideas around, evaluate customer response, negotiate for funding and mobilize resources (Anderson, Jack \& Dodd, 2005; Steier, 2001; Steier, 2007). All these activities involve social interactions - interactions with a context - that provides conditions from which opportunities can be created and boundaries set (Welter, 2011). Hence, we have recently seen an increased attention to 'context' in entrepreneurship literature, where entrepreneurship is viewed as an interactive process rather than referred to as a specific individual (Gaddefors and Anderson, 2017; Korsgaard, Ferguson and Gaddefors, 2015a; Watson, 2013; Welter, 2011).

Context has often been understood as background, surroundings or the external environment (Cappelli and Sherer, 1991) that the entrepreneur acts within (Boettke and Coyne, 2009). A more developed view is taken by Welter (2011, p. 167) when she describes context as "circumstances, conditions, situations, or environments that are external to the respective phenomenon and enable or constrain it". In this seminal work, the interface between entrepreneurship and context is a two-way interaction, meaning that context can both influence and be influenced by entrepreneurship. 
A theoretical concept that captures the interaction with context is 'identity' (Fletcher, 2003; Dodd and Anderson, 2007). Identity has been used to explain the recursive links between the individual and the social (Gaddefors and Anderson, 2009) and even the interaction between entrepreneurship and social context (Fauchart and Gruber, 2011). Thus, we argue that focusing on identities may initiate investigation into the interaction between entrepreneurship and context. We find this interaction to be essential to a better understanding of entrepreneurial development and how firms and markets take form.

\subsection{Identity on three levels}

The concept of identity is receiving increased interest from scholars within several different fields, including entrepreneurship and marketing (Gaddefors, 2005; Cornelissen et al., 2007; Balmer, 2008). Identity has been approached at the micro and macro levels, yet few contributions have explored how different ideas of identity interact, (i.e. how identity works between levels) (Cornelissen et al., 2007). In this chapter, we present and discuss individual identity, corporate identity and market identity. Following this, we discuss how individual, corporate and market identity combine, and argue that the concept of identity is key in constructing new firms and markets.

\subsubsection{Individual identity}

In entrepreneurship literature, the concept of identity primarily concerns an entrepreneur's individual identity (Danes and Jang, 2013). Individual identity has been understood as a product (what it is) or a process (how it is shared) (Pratt, 2003 in Danes and Jang, 2013). Identity as a process is constructed in a social context and influenced by one's own and other peoples' beliefs, values, feelings and actions (Fauchart and Gruber, 2011). Lindgren and Wåhlin (2001, p. 358) refer to this as "reflexive identity construction" and explain that it is a process that builds on "social interaction and repeated self-reflexion". Hence, identity is not static, but rather constantly reformulated in interaction with others (Lindgren and Wåhlin, 2001; Watson, 2008; Lindgren and Packendorff, 2009). This processual understanding of identity has been referred to as "identity work" (e.g. Sveningsson and Alvesson, 2003; Watson, 2008; Down and Reveley, 2004), and is built on a distinction between internal self-identities and external social-identities. Following Watson (2008), we understand self-identity as "the individual's own notion of who and what they are" (p. 131) and social-identities as "cultural, discursive or institutional notions of who or what any individual might be" (p. 131). Pratt (2003) views these types of identities as two different sides of the same coin, and describes them as two dimensions of identity: the personal dimension (self-reflecting on who I am) and the social dimension (self-reflecting on who we are) (in Danes and Jang, 2013). Thus, identity is connected to a person's sense of belonging (or not belonging), and to social groups, which provide the individual with a perceived frame of reference (Fauchart and Gruber, 2011). These bases for identification are sometimes competing and can appear differently in different social settings (Watson, 2008). However, the influence that discourses and social identities have on a person's self-identity is not merely one-way; a person's self-identity can also influence social identities and discourses (Watson, 2008).

\subsubsection{Corporate identity}

Turning to the marketing literature and the corporate level, we depart from the concept of corporate identity (Blombäck and Brunninge, 2009; Cornelissen et al., 2007; Whetten, 2006; Whetten and Mackey, 2002). The meaning of corporate identity has not always been consistent in previous literature, and there are several affiliated concepts (Balmer, 2008) that can sometimes cause confusion as writers do not always specify how they define these terms. For example, a concept closely affiliated with corporate identity is organizational identity (Balmer, 2008). Traditionally, these two concepts have been used to address different research questions (Cornelissen et al., 2007). Whereas research in organization theory has focused on systems of shared meanings and how members conceive organizational identity (Whetten, 2006; Whetten \& Mackey, 2002), research on corporate identity has primarily focused on the projection 
of an image and how identity is communicated to an external audience (Blombäck \& Brunninge, 2009; Cornelissen et al., 2007; Goia, Schultz \& Corley, 2000). However, during the last decade, research within these two areas has moved closer together. The view of corporate identity now commonly concerns the projected image of an organization, yet includes its underlying organizational features (Cornelissen et al., 2007). In this paper, we have chosen to use the concept 'corporate identity', as we focus on how identity interacts with the market. We see corporate identity as being concerned with what the organization is (Balmer and Gray, 2003) and what it seeks to be (Abratt \& Kleyn, 2012), i.e. the organizational features that make it unique and the intent for this identity to be translated to the market. This comprises the organization's strategic choices (derived from core values and culture) and how it elects to express these (Abratt \& Kleyn, 2012). Thus, we may include the organization's vision and strategies for positioning and differentiating their business (Hatch and Schultz, 2001; Melewar and Karaosmanoglu, 2006; Rode and Vallaster, 2005). Balmer (2008) tries to sort amongst the different perspectives on identity and describes some schools of thought concerning identity and identification as corporate identity (identity of the corporation), corporate identification (identification from the corporation), stakeholder identification (identification with the corporation) and corporate cultural identification (identification with a corporate culture). From our perspective, these four schools are mirrored in the identity work of individuals, companies and markets, which will be discussed in this paper. We thus apply a holistic perspective to corporate identity.

\subsubsection{Market identity}

Finally, we turn to market identity, sometimes referred to as industry identity (Melewar and Karaosmanoglu, 2006), which is a collectively shared identity between members in a market (Navis and Glynn, 2010). Market identity has been defined as "the social categories that specify what to expect of organisations and products that claim that identity" (Jensen, 2010, p. 40). Thus, the collective identity of a market adheres around a prototype, i.e. the best representation of what it means to be a member of that specific market (Navis and Glynn, 2010). However, members are not identical and thereby vary in the extent to which they conform to the prototype (Navis and Glynn, 2010). Instead, market identity becomes a common denominator that companies have to relate to. A company's corporate identity will thus be influenced by the industry in which it competes (Melewar and Karaosmanoglu, 2006). This may create a challenge for members in navigating between the collective market identity and the identity of their organization, i.e. on one hand what makes the company similar to others in the market (what makes it belong), and on the other hand what makes the company different and unique (Navis and Glynn, 2010). Hence, the interactions between firms in a market consist not only of competition, but also of cooperation and coordination (Vargo and Lusch, 2004; 2016).

\subsubsection{How identities interact to create new firms and markets}

The concept of identity has been approached on the individual, corporate and market levels. Yet few contributions have explored how these different levels of identity interact (Cornelissen et al., 2007) as new firms and markets are developed. Even if scholars in marketing have investigated how corporate identity may be developed and sustained, the focus has been on large and established corporations (Abimbola and Kocak, 2007; Ahonen, 2008), where relatively little research has been devoted to how corporate identity is created in start-ups (Abimbola and Vallaster, 2007; Abmibola and Kocak, 2007), and even less has focused on new markets (Santos and Eisenhardt, 2009; Jensen, 2010). However, there are exceptions in the literature, such as Fauchart and Gruber (2011), who discuss how corporate identity in start-ups is constructed by the founder in interaction with context. Fauchart and Gruber $(2011$, p. 937) state that this is "both because organisational decisions are often made by a single person (the founder) and because emerging firms are typically small entities that are yet to be shaped". Hence, the founder's identity impacts the organization's vision (through setting goals, imposing values and core philosophy), 
structure (through deciding on how to organize and allocate competencies) and culture (through employing and introducing staff, and imposing values and norms). The early developing identity often leaves an impression on the organization for a long time to come (Melewar and Karaosmanoglu, 2006). Rindova, Petkova and Kotha (2007) show how the founder can serve as the very face of a firm, and how the founder's identity creates legitimacy for the business. As new members are involved in the organization, they too will influence corporate identity by bringing values, behaviours and attitudes to the company, which will influence organizational culture, communication with stakeholders and perhaps even strategies and visions. Hence, "corporate identity is continuously (re)formulated, in processes that simultaneously influence internal and external audiences" (Blombäck and Brunninge, 2008, p. 404).

Likewise, market identity has chiefly been investigated in established markets, and has then been concerned with the positioning and compliance of companies to a market, whilst the developing of a new market identity has been neglected. In one of the few contributions, Jensen (2010) argues that a new market identity can be created by combining existing categories in new ways. Navis and Glynn (2010) explain that just as market identity is collectively shared, it is also collectively constructed as members emphasize similarities across firms. When a new market is taking shape, the first few actors are pivotal in constructing the emerging market identity. These actors often put a lot of effort into claiming the market, meaning they simultaneously define an identity for the company as well as the market so that the two become synonymous (Santos and Eisenhardt, 2009). If this is done successfully, the company will become the cognitive referent for other actors as they claim membership to the market. Examples of this are Rollerblades being the referent for in-line skates, iPad being the referent for eReaders or tablets and Jacuzzi being the referent for whirlpools. Thus, as new actors enter the market, they need to build on similarities to the present members in order to claim membership (Navis and Glynn, 2010). The collective market identity thereby becomes the basis for members, within which they develop their own distinctive identities (Navis and Glynn, 2010). New members will of course have an impact on the market context as they bring values, behaviours and increased competition. In doing so, they join in the constant (re)creation of the market identity as they interact with the other members.

To sum up, we have illustrated how identities of individuals, firms and markets combine, and argued that these theoretical concepts can help better understand entrepreneurial processes in developing firms and markets.

\section{Method and Cases}

Our overall research interest was in entrepreneurial processes and marketing activities in new markets. In 2007, the first trembling steps were taken towards what was to become the meal-kit market in Sweden. A woman came up with a novel idea on how to facilitate Swedish consumers' everyday efforts in deciding what to make for dinner, looking for recipes, making shopping lists and finding the time and energy to shop for groceries and get home. She started a firm that provided meal kits (food products and recipes) that were delivered to the customers' doorsteps. Shortly after the first firm saw the light of day, other small firms were created and started to offer similar services all over Sweden, but with a concentration around the urban areas of central Sweden. In 2010, when the market was still in its infancy, we succeeded in establishing contact with ten of the 20 initiatives that were active in Sweden at the time. Amongst them we found three established retailers that were in the process of opening up meal-kit divisions. As our longitudinal study proceeded, we added a few more cases over the years, but our main focus came to be the early start-ups that we had the opportunity to follow from the market's nascent stage. Thus, our research is based on multiple case studies (Eisenhardt, 1989), and in this article we report on five of the 
early start-ups (see Table 1). As stated by Morrow (2005), focusing on a few individuals permits a contextsensitive approach. These five companies were selected based on four criteria - they entered the market at an early stage, they offer similar products, they have similar categories of customers, and they are located in similar geographical areas. These similarities lead us to argue that they act in the same market, which is confirmed by the founders themselves, who often refer to each other's businesses. However, despite the firms being similar in many ways, they also express some minor distinctions in our four criteria (market entry, product differentiation, consumer category, geographical market) that make each business unique (see Table 1). This sampling process was designed to enable insights into how identity works in entrepreneurial processes and to facilitate comparisons between cases and within cases in our analytical work (Glaser and Strauss, 1967). In order to preserve the integrity of our interviewees, we have anonymized our cases. To make it easier to keep track of which founder belongs to which company, we have given them names that begin with the same capital letter; for example, Helena and Homer at HomeGrown, and Petra at Peaceful Dinner.

Table 1. The meal-kit start-ups.

\begin{tabular}{|c|c|c|c|c|}
\hline $\begin{array}{l}\text { Interviewed } \\
\text { founder, } \\
\text { FIRM }\end{array}$ & Market entry & $\begin{array}{l}\text { Product } \\
\text { differentiation }\end{array}$ & Consumer category & Geographical market \\
\hline $\begin{array}{l}\text { Petra } \\
\text { PEACEFUL DINNER }\end{array}$ & October 2007 & $\begin{array}{l}\text { Focused on health } \\
\text { and sustainability, } \\
\text { and in educating } \\
\text { customers on what } \\
\text { and how to eat. }\end{array}$ & $\begin{array}{l}\text { Households of } 4 \\
\text { people. }\end{array}$ & $\begin{array}{l}\text { Locally started in } \\
\text { Stockholm. } \\
\text { Have expanded to a } \\
\text { national market, } \\
\text { including Uppsala and } \\
\text { Västerås. Also delivers } \\
\text { to some cities in } \\
\text { neighbouring counties. }\end{array}$ \\
\hline $\begin{array}{l}\text { Helena and Homer } \\
\text { HOME-GROWN }\end{array}$ & $\begin{array}{l}\text { September } \\
2009\end{array}$ & $\begin{array}{l}\text { Focused on products } \\
\text { from local farmers, } \\
\text { and organic products. }\end{array}$ & $\begin{array}{l}\text { Households of 4-5 } \\
\text { people. Offer a } \\
\text { vegetarian } \\
\text { alternative and } \\
\text { alternatives for } \\
\text { customers with } \\
\text { gluten or lactose } \\
\text { intolerances. }\end{array}$ & $\begin{array}{l}\text { Locally started in } \\
\text { Västerås. Have not } \\
\text { expanded outside the } \\
\text { city. }\end{array}$ \\
\hline $\begin{array}{l}\text { Olga and Olivia } \\
\text { ORGANIC DINNER }\end{array}$ & Autumn 2009 & $\begin{array}{l}\text { Strictly focused on } \\
\text { organic products } \\
\text { (connected to health } \\
\text { and sustainability). }\end{array}$ & $\begin{array}{l}\text { Households of } 4 \\
\text { people. Offers a } \\
\text { vegetarian } \\
\text { alternative. }\end{array}$ & $\begin{array}{l}\text { Locally started in } \\
\text { Stockholm. Have } \\
\text { expanded to Uppsala. }\end{array}$ \\
\hline $\begin{array}{l}\text { Emily } \\
\text { EMILY'S DINNER }\end{array}$ & $\begin{array}{l}\text { December } \\
2009\end{array}$ & $\begin{array}{l}\text { Focused on quality in } \\
\text { general (involving } \\
\text { organic when } \\
\text { financially } \\
\text { motivated). }\end{array}$ & $\begin{array}{l}\text { Households of } 4 \\
\text { people. Eventually } \\
\text { adds households of } 2 \\
\text { people. }\end{array}$ & $\begin{array}{l}\text { Locally started in } \\
\text { Västerås. Have not } \\
\text { expanded outside the } \\
\text { city. }\end{array}$ \\
\hline $\begin{array}{l}\text { David } \\
\text { DINNER-TIME }\end{array}$ & January 2011 & $\begin{array}{l}\text { Focused on overall } \\
\text { quality. Local, and } \\
\text { organic when } \\
\text { financially } \\
\text { motivated. }\end{array}$ & $\begin{array}{l}\text { Households of } 4 \\
\text { people. }\end{array}$ & $\begin{array}{l}\text { Locally started in } \\
\text { Uppsala. }\end{array}$ \\
\hline
\end{tabular}


Data was collected at different points in time. The main author of this article interviewed the founders three times, followed them online and in the media, and studied written material such as policy documents and commercial material (Alvesson, 2003; Silverman, 1993). Rich material was provided through evolving relationships with the founders (Morrow, 2005), and by visiting the founders several times, we acquired three advantages. First, by developing a relationship to the organizations we got to meet employees, which gave us more detailed knowledge about the workings of the company. Secondly, visiting the firms several times improved our understanding of what was at stake in the organizations. Thirdly, consecutive visits gave us the opportunity to check ambiguities, which we complemented with further questions and developed analytical ideas based on responses. To provide in-depth data, the number of questions was kept low in order to give the interviewee the opportunity to present his or her own narrative about what had occurred in the venture over time (Morrow, 2005). The face-to-face interviews were recorded and transcribed.

To build trustworthiness (Morrow, 2005), we collected data from multiple sources so as to place the material in context (Alvesson and Deetz, 2000). One advantage of collecting multiple viewpoints about the same case is that this avoids misunderstandings and deviants (Alvesson and Kärreman, 2001). It also enables comparing statements from different sources given at different times, allowing us to evaluate the statements for consistency (Morrow, 2005). These evaluations may also reveal biases towards our way of asking questions (Gaddefors, 2005). Tracking the cases over time gave us the opportunity to follow the progression of the organizations. But perhaps more importantly, it gave us insights into what constitutes context and how entrepreneurship and context interact when a new market is developing.

In our work to describe the stories from the field (Czarniawska, 2007), we developed themes by re-reading interview extracts and combining our interpretations with recursive involvement from theoretical accounts (Glaser, 1978). In an iterative process between empirics and theory, ideas developed when we compared, combined and problematized (Sandberg and Alvesson, 2011) what we learned from our cases. The themes were sorted using the software ATLAS.ti. In the first empirically grounded round of coding, we ended up with 76 categories. In the next round, theory was given stronger influence and the number of categories decreased to 11. After the third round, a number of concepts emerged which fulfilled our aims. In Table 2, we provide examples of how this was conducted, i.e. examples of our analytical process of creating notes, categorizing interview quotes and grounding them in concepts. In the process of shaping empirical as well as theoretical understandings into a coherent contribution, we aimed for a reflexive stance; in other words, clarity about how our perspectives influenced our results (Fletcher, 2007; Alvesson and Deetz, 2000).

\section{Findings and discussion}

The focus in this study is on identity as a process, where the findings will illustrate how identity flows as founders, firms and the market are developing.

\subsection{Findings}

An overview of what happened in our five cases is displayed in Table 3. Here, we focus on three main levels of identity:

1) Individual identities of the founders and their identity work - how the founders see themselves and how context affects their identities and aspects of individual identity related to the meal-kit business (i.e. their food philosophy, which can be a way of self-expression, and their identity as entrepreneurs). 
2) Corporate identity and its identity work - how the firm is affected by the founder's individual identity and how the context of the new market affects this corporate identity

3) Market identity and its identity work - how the market is affected by firms and individuals. (Please note that the examples brought up in Table 2 correspond to two of the cells in Table 3.)

Table 2. Example of how quotes were turned into analytical notes, categorized and allocated to concepts

\begin{tabular}{|c|c|c|c|}
\hline Quotes & Analytical notes & Categories & Concepts \\
\hline \multicolumn{3}{|l|}{ Market entry 2007-2010 (retrospect.) } & \multirow{13}{*}{$\begin{array}{l}\text { Individual } \\
\text { identity and its } \\
\text { identity work }\end{array}$} \\
\hline $\begin{array}{l}\text { "It started with me arranging my first 'dinner with the girls' } \\
\text { when I was } 18 \text { and then it continued. When I had my first child } \\
\text { in } 2001 \text {, I became really interested in food quality." }\end{array}$ & \multirow{4}{*}{$\begin{array}{l}\text { Has a strong food } \\
\text { philosophy, concerning } \\
\text { healthy homemade food } \\
\text { without additives that is } \\
\text { produced in a sustainable } \\
\text { way. }\end{array}$} & \multirow[t]{4}{*}{$\begin{array}{l}\text { Founder's food } \\
\text { philosophy/ } \\
\text { values. }\end{array}$} & \\
\hline $\begin{array}{l}\text { "I learned the basics from mom and then I read a lot and tried } \\
\text { my hand at it." }\end{array}$ & & & \\
\hline $\begin{array}{l}\text { Talking about what is important when choosing food products: } \\
\text { "[...] how the food is produced, where it comes from, issues } \\
\text { concerning feed and cultivation, pesticides, etc." }\end{array}$ & & & \\
\hline $\begin{array}{l}\text { "Food was actually better in the old times [...] when there was } \\
\text { less cadmium in the wheat, less E-numbers and pesticides and } \\
\text { no poisonous packaging... just that you could buy all food in } \\
\text { bulk over a counter and now everything is packed in God knows } \\
\text { which plastic." }\end{array}$ & & & \\
\hline $\begin{array}{l}\text { "Others would probably describe me as very committed and I } \\
\text { have strong opinions that I like to make known. But I'm not a } \\
\text { classic entrepreneur." }\end{array}$ & \multirow{2}{*}{$\begin{array}{l}\text { Does not see herself as } \\
\text { an entrepreneur, but } \\
\text { rather as a professional } \\
\text { manager. } \\
\text { Refers to the prevailing } \\
\text { discourse of an } \\
\text { entrepreneur. }\end{array}$} & \multirow[t]{2}{*}{ Founder's identity } & \\
\hline $\begin{array}{l}\text { "I have not previously worked with food, but I worked as a } \\
\text { management consultant and worked with efficient processes, } \\
\text { process development, IT, telecom. I have been a fairly driven } \\
\text { project manager." }\end{array}$ & & & \\
\hline $\begin{array}{l}\text { "When I started as a consultant, I had several colleagues who } \\
\text { resigned to start their own businesses, and I could almost } \\
\text { disdain them; that they wanted to be self-employed! I had all } \\
\text { these thoughts that business owners were alone, had no life; it } \\
\text { is only risks, no vacation. I almost felt sorry for them. But I have } \\
\text { succeeded in rebutting this." }\end{array}$ & \multirow[t]{2}{*}{$\begin{array}{l}\text { Believes being a founder/ } \\
\text { entrepreneur is not for } \\
\text { her. } \\
\text { Ideas about what an } \\
\text { entrepreneur is, } \\
\text { influenced by the general } \\
\text { discourse. }\end{array}$} & \multirow[t]{2}{*}{$\begin{array}{l}\text { Founder's identity } \\
\text { Change in } \\
\text { founder's identity }\end{array}$} & \\
\hline $\begin{array}{l}\text { "I was not thinking I'd start it myself, but rather thinking that } \\
\text { this is the company I want to work for. Later that day I had } \\
\text { lunch with a former colleague and told him that I had the } \\
\text { greatest idea and just needed to find someone who could start } \\
\text { this company so that I could take up employment there." }\end{array}$ & & & \\
\hline $\begin{array}{l}\text { "Then he said, [Petra] just stop it! Of course you should start } \\
\text { it!" }\end{array}$ & \multirow{2}{*}{$\begin{array}{l}\text { Encouraged to start the } \\
\text { firm by a friend and her } \\
\text { husband. }\end{array}$} & \multirow[t]{2}{*}{$\begin{array}{l}\text { Influence from } \\
\text { others }\end{array}$} & \\
\hline $\begin{array}{l}\text { "He supported me } 100 \text { per cent [...] his motto is: how hard can } \\
\text { it be?" }\end{array}$ & & & \\
\hline \multicolumn{3}{|l|}{ Spring 2011} & \\
\hline $\begin{array}{l}\text { "I think I am more the kind of entrepreneur who found 'my } \\
\text { thing', rather than someone who has sniffed out profitable } \\
\text { ideas" }\end{array}$ & $\begin{array}{l}\text { Is now referring to } \\
\text { herself as an } \\
\text { entrepreneur by } \\
\text { changing her ideas on } \\
\text { what an entrepreneur is. }\end{array}$ & $\begin{array}{l}\text { Founder's identity } \\
\text { Change in } \\
\text { founder's identity }\end{array}$ & \\
\hline
\end{tabular}


Table 3. Descriptions of and interactions between the founders' individual identity, the firms' corporate identity and the market identity in five cases.

\begin{tabular}{|c|c|c|c|}
\hline Time & Individual identity and its identitywork & Corporate identity and its identitywork & Market identity and its identitywork \\
\hline \multicolumn{4}{|c|}{$\begin{array}{l}\text { Petra, } \\
\text { PEACEFUL DINNER }\end{array}$} \\
\hline $\begin{array}{l}\text { Market entry } \\
\text { October } 2007 \\
\text { (retrospect.) }\end{array}$ & $\begin{array}{l}\text { Does not see herself as an entrepreneur, but rather as a } \\
\text { professional manager. } \\
\text { Has a strong food philosophy valuing healthy, homemade } \\
\text { food without additives, produced in a sustainable way. }\end{array}$ & $\begin{array}{l}\text { Corporate identity builds on the founder's values } \\
\text { concerning food and management. The core values are } \\
\text { sustainability, professionalism and curiosity, which are } \\
\text { reflected in organization, strategies, HR, etc. }\end{array}$ & $\begin{array}{l}\text { Market identity is created and claimed by Petra. } \\
\text { Customers in the market interact personally with Petra } \\
\text { while forming their understanding of the meal-kit } \\
\text { market. }\end{array}$ \\
\hline Spring 2011 & $\begin{array}{l}\text { Is now referring to herself as an entrepreneur, partly } \\
\text { influenced by a friend and her husband. Adjusts her own } \\
\text { definition of what an entrepreneur is. }\end{array}$ & $\begin{array}{l}\text { Responds to competition by emphasizing that they are } \\
\text { the high-quality alternative. } \\
\text { Adapts to market trends that do not value environmental } \\
\text { considerations by altering the presentation of the firm. } \\
\text { Have established routines for customer feedback. }\end{array}$ & $\begin{array}{l}\text { Market identity is developed as other actors enter the } \\
\text { market. The new direction is unwanted by Petra as trade- } \\
\text { offs are made which lower the food safety. } \\
\text { Customers provide regular feedback to Peaceful Dinner. }\end{array}$ \\
\hline Autumn 2012 & $\begin{array}{l}\text { Has turned over the CEO position to her husband, } \\
\text { explaining that she does not relate to being a manager any } \\
\text { more. Instead she describes herself as an influencer in food, } \\
\text { health and sustainability. }\end{array}$ & $\begin{array}{l}\text { Still focus on being the high-quality alternative. } \\
\text { Slightly changing corporate values in order to adapt to } \\
\text { demands for new products (meal kit for children). } \\
\text { Corporate identity becomes important in every decision, } \\
\text { i.e. founder experiences that collaborations will affect } \\
\text { corporate identity. } \\
\text { Home-visits to customers to observe and learn. }\end{array}$ & $\begin{array}{l}\text { Market identity keeps developing as other actors enter } \\
\text { the market. Petra feels the need to claim the position as } \\
\text { the original meal-kit alternative. Tries to take the lead by } \\
\text { inventing and launching new products. } \\
\text { Customer demand for new products (i.e. a meal kit } \\
\text { adapted to children). }\end{array}$ \\
\hline \multicolumn{4}{|c|}{$\begin{array}{l}\text { Helena and Homer, } \\
\text { HOME-GROWN }\end{array}$} \\
\hline $\begin{array}{l}\text { Market entry } \\
\text { September } \\
2009 \\
\text { (retrospect.) }\end{array}$ & $\begin{array}{l}\text { Strong food philosophy valuing local and organic food. } \\
\text { See themselves as entrepreneurs who strive to make a } \\
\text { living, but not 'businessmen'. } \\
\text { Value their local community and commit by assisting social } \\
\text { services, engaging in efforts to help misplaced children, } \\
\text { helping local farmers to sell products. }\end{array}$ & $\begin{array}{l}\text { Firm is inspired by the new market. When the founders } \\
\text { heard of the meal-kit concept they were discussing ways } \\
\text { of linking local organic farmers to end-consumers. } \\
\text { Corporate identity is built on the founders' personal food } \\
\text { philosophy favouring locally and organically produced } \\
\text { food and linking local farmers to consumers. }\end{array}$ & $\begin{array}{l}\text { Peaceful Dinner is seen as the main referent on the } \\
\text { market, which inspires the start of Home-Grown. } \\
\text { Home-Grown adds by focusing on the link to the local } \\
\text { farmer. }\end{array}$ \\
\hline Spring 2011 & & $\begin{array}{l}\text { Some concessions and trade-offs on food being organic } \\
\text { and local in order to find enough food supplies. } \\
\text { View their product as different from other actors. } \\
\text { Affected by other actors' pricing strategies. }\end{array}$ & Perceived price competition in market. \\
\hline $\begin{array}{l}\text { Autumn } 2012 \\
\text { (firm is sold } \\
\text { off) }\end{array}$ & $\begin{array}{l}\text { Are no longer owners - have sold off Home-Grown to focus } \\
\text { on their core business, to have more time for family and to } \\
\text { take care of their children and employees. Feel a need to } \\
\text { make a living for themselves. }\end{array}$ & $\begin{array}{l}\text { Corporate identity is influenced as choices of food } \\
\text { products are changed in accordance with the trade-offs } \\
\text { made by the new owner. The old owners now recognize } \\
\text { that they (as individuals) were the brand. }\end{array}$ & $\begin{array}{l}\text { Customers regularly interact with the founders and the } \\
\text { firm at arranged events at the local farm, for example } \\
\text { markets in the spring, autumn and Christmas. }\end{array}$ \\
\hline \multicolumn{4}{|c|}{$\begin{array}{l}\text { Holly (new owner) } \\
\text { HOME-GROWN }\end{array}$} \\
\hline $\begin{array}{l}\text { Autumn } \\
2012\end{array}$ & $\begin{array}{l}\text { Values local production. Engages in promoting local } \\
\text { farmers. }\end{array}$ & $\begin{array}{l}\text { Made some trade-offs on food being organic and local in } \\
\text { order to lower costs. } \\
\text { Responds to other actors by adding similar products, i.e. } \\
\text { a meal kit for children and an organic fruit basket. } \\
\text { Starts to collect feedback (a questionnaire) from } \\
\text { customers in order to develop menus. }\end{array}$ & $\begin{array}{l}\text { Customer demand for new products (i.e. a meal kit } \\
\text { adapted to children). } \\
\text { Customers provide feedback through questionnaire. }\end{array}$ \\
\hline
\end{tabular}




\begin{tabular}{|c|c|c|c|}
\hline \multicolumn{4}{|c|}{$\begin{array}{l}\text { Olga and Olivia, } \\
\text { ORGANIC DINNER }\end{array}$} \\
\hline $\begin{array}{l}\text { Market entry } \\
\text { autumn } 2009 \\
\text { (retrospect.) }\end{array}$ & $\begin{array}{l}\text { Strong personal food philosophy valuing organic food. } \\
\text { See themselves as entrepreneurs. }\end{array}$ & $\begin{array}{l}\text { Corporate identity created from the founders' values of } \\
\text { health, sustainability and pleasure (appetite), striving for } \\
\text { a fully organic meal kit. Use national celebrities to } \\
\text { reinforce the corporate identity. } \\
\text { The founders were looking for business ideas on how to } \\
\text { promote organic food. Engage in focus groups with } \\
\text { potential customers. }\end{array}$ & $\begin{array}{l}\text { Peaceful Dinner is seen as the main referent on the } \\
\text { market, which inspires the start of Organic Dinner. } \\
\text { Potential customers co-create the concept during focus } \\
\text { group meetings. }\end{array}$ \\
\hline Spring 2011 & Believe their identities have not changed. & $\begin{array}{l}\text { Corporate identity is preserved. The founders watch the } \\
\text { other actors in the market but stick to their specific niche } \\
\text { of fully organic meal kits. }\end{array}$ & $\begin{array}{l}\text { Do not perceive the others as direct competitors, but } \\
\text { rather partners developing the market together. }\end{array}$ \\
\hline Autumn 2012 & Believe their identities have not changed. & $\begin{array}{l}\text { Stick to their market niche as the full organic alternative. } \\
\text { Respond to customer preferences by slightly modifying } \\
\text { how values are presented. } \\
\text { Watch other actors and copy profitable products (i.e. a } \\
\text { vegetarian meal kit and an organic fruit basket). } \\
\text { Marketing surveys of customers who have unsubscribed. } \\
\text { Measures customers' ranking of menus on website. } \\
\text { Has moved to new facilities, expanded to more cities and } \\
\text { employed a manger. }\end{array}$ & $\begin{array}{l}\text { The meal-kit market is known to most customers, } \\
\text { according to Olga and Olivia. } \\
\text { Product development in the market as different market } \\
\text { actors try out their ideas. }\end{array}$ \\
\hline \multicolumn{4}{|c|}{$\begin{array}{l}\text { Emily, } \\
\text { EMILY'S DINNER }\end{array}$} \\
\hline $\begin{array}{l}\text { Market entry } \\
\text { December } \\
2009 \\
\text { (retrospect.) }\end{array}$ & $\begin{array}{l}\text { Sees herself as an entrepreneur and wants to be self- } \\
\text { employed. } \\
\text { Does not express any strong food philosophy. } \\
\text { Identifies herself as being part of an entrepreneuring } \\
\text { family, where most of the adults are self-employed. Several } \\
\text { of the family firms are involved with food (suppliers, } \\
\text { deliverers, processors). }\end{array}$ & $\begin{array}{l}\text { Corporate identity inspired by other actors (Peaceful } \\
\text { Dinner) and a perceived market demand for high-quality } \\
\text { food. } \\
\text { Competitive advantage from ties to family firms. } \\
\text { Seeks input from friends, relatives and potential } \\
\text { customers. Receives regular input from customers due to } \\
\text { being involved in deliveries. }\end{array}$ & $\begin{array}{l}\text { Other actors in the market inspire the start of Emily's } \\
\text { Dinner. Peaceful Dinner is one of the referents. } \\
\text { Customers and others provide feedback. }\end{array}$ \\
\hline Autumn 2010 & $\begin{array}{l}\text { Still sees herself as an entrepreneur. Thus, feels a need to } \\
\text { justify why her business has not reached its goals. } \\
\text { The founder claims that she cannot relate to the corporate } \\
\text { identity. }\end{array}$ & $\begin{array}{l}\text { Corporate identity is still inspired by the broad market. } \\
\text { Adjusts to other actors, but also innovates, for example } \\
\text { meal kits for barbeques and Fridays. } \\
\text { Adjusts to customer demands by adding a meal kit for } \\
\text { two-person households. } \\
\text { Customer input from doing deliveries. Also planning } \\
\text { for customer surveys. }\end{array}$ & $\begin{array}{l}\text { Other market actors provide inspiration for the firm. } \\
\text { Customers and potential customers provide feedback to } \\
\text { the firm. }\end{array}$ \\
\hline Autumn 2011 & $\begin{array}{l}\text { Still sees herself as an entrepreneur. Thus, feels a need to } \\
\text { justify why her business has not reached its goals. } \\
\text { The founder claims that she cannot relate to the corporate } \\
\text { identity, and feels a need to adjust it to better fit who she } \\
\text { is as a person. }\end{array}$ & $\begin{array}{l}\text { Corporate identity is developed after discussions with } \\
\text { others (friends, relatives, potential customers), into "a } \\
\text { local initiative supporting other local firms". } \\
\text { Brand mark is changed to better fit the founder. } \\
\text { Adjusts to other actors, but also innovates to } \\
\text { differentiate. } \\
\text { Still delivers the meal kits herself. } \\
\text { Customer input from doing deliveries. Still planning } \\
\text { for customer surveys. }\end{array}$ & $\begin{array}{l}\text { Other market actors provide inspiration for the firm. } \\
\text { Customers and potential customers provide feedback to } \\
\text { the firm. }\end{array}$ \\
\hline
\end{tabular}


David,

DINNER-TIME

\begin{tabular}{l|l} 
Market entry & $\begin{array}{l}\text { Sees himself as an entrepreneur and has previous } \\
\text { January 2011 } \\
\text { experience in being self-employed. Dreams of creating a }\end{array}$ \\
\hline (etrospect) & busness developing and
\end{tabular}

business and developing an organization.

Does not express any strong food philosophy.

Spring 2011

Autumn 2012 Does not express any strong food philosophy.

Corporate identity inspired by other actors and builds on a perceived market demand for locally produced meal kits of high quality.

Seeks input from friends and acquaintances.

Customer input from doing deliveries.

Planning for a market survey to customers.

Customer input from sometimes doing deliveries.

corporate identity questioned by stakeholders for not

having a specific niche, which frustrates the founder.

Follows and adjust to other actors by copying profitable

ideas (meal kits with fewer dinners, fruit baskets).

Tries to innovate to find competitive advantages, i.e.

offering additional e-shopping of groceries.

Seeks feedback from customers by employing a call

centre and through weekly questionnaires to customers.
Other actors in the market inspire the start of Dinner-

Time.

Customers and others provide feedback.

Other market actors provide inspiration for the firm.

Customers provide feedback.

Other actors provide inspiration for the firm.

Customers provide feedback. 
In the next section, we present a more detailed account of what occurred in the five firms (for illustrative purposes) as we discuss the findings.

\subsection{How individual identity interacts with corporate identity}

In our cases, the founders' individual identities influence the corporate identities of the start-ups. This is done through influencing everything from the companies' visions and strategies for positioning and differentiation, to organizational culture, behaviour and communication (Fauchart and Gruber, 2011; Melewar and Karaosmanoglu, 2006; Whetten and Mackey, 2002). The founders set the agenda for their companies and as most of them are still small, the founders continue to have decisive influence on the corporate identity. However, some founders put more of their personal identity into the corporate identity than others. For example, Petra, Helena and Homer, and Olga and Olivia, build their firms on their individual food philosophies, whereas Emily and David draw inspiration from the prevailing food philosophy in the general market. "We take their concept and make it better" (David). We also saw the converse situation, where the corporate identity influenced the founder's identity. For example, the founders explain how they as individuals have changed through learning the day-to-day activities of running a business. One example is Petra, who, when she started to refer to herself as an entrepreneur, did this partly by adjusting her own identity, but also by adjusting her perception of what constitutes an entrepreneur. "I had all these thoughts that business owners were alone, had no life; it is only risk, no vacation. I almost felt sorry for them. But I have succeeded in rebutting this. [...] I think I am more the kind of entrepreneur who found 'my thing', rather than someone who has sniffed out profitable ideas" (Petra). Eventually, she changed to better match the expectations of an entrepreneur. However, it is not a question of surrendering to social pressure. In our case, Petra stood up for her own individual identity and stepped down from being the CEO of the firm. She justified this decision by saying that she is not good with accounting. Instead, she placed greater focus on her role as a food influencer, i.e. engaging in social media and participating in interviews and panel discussions in public media and other events, which she claims is more in line with "who she is". Thus, we saw how identity had a personal and a social dimension, and how identity work (Sveningsson and Alvesson, 2003; Watson, 2008; Down and Reveley, 2004) developed our founders' sense of belonging in the firms.

In our cases, some firms use the founder's identity as the face of the business, and some display identities from other individuals. An example of the former is Helena and Homer, who are well-known in their local community. "I felt like it was me and [Homer] who were the brand. All our first and oldest customers saw us as an assurance for it to be good and as we had imagined it from the beginning. I think we had customers who simply stayed with us to support us" (Helena). Examples of the latter include Olga's and Olivia's firm, which uses national celebrity customers in marketing; and David, who chooses to feature the chefs creating the recipes. No matter who is fronting the firm, and if the person is known or unknown by the audience, this will cause individual identity to spill over to corporate identity. We understand this as an attempt to create legitimacy for the business and perhaps a way to ease the liability of newness (Bruderl and Schussler, 1990; Freeman et al., 1983; Singh, Trucker \& House, 1986; Stinchcombe, 1965; Witt \& Rode, 2005). Thus, being the face of the firm creates a bond between individual and firm - and with this bond comes expectations. For example, Emily presented herself as the face of her new firm, but eventually the firm developed in a slightly different direction from what she expected and she felt hesitant to remain the face of something she did not fully stand behind. "I haven't really been able to identify myself with this firm [Emily's Dinner]. I haven't felt that it's me. It has therefore been difficult to market it, as I haven't been able to really stand for it" (Emily). Her response was to put more effort into adjusting the corporate identity to her own individual identity. In this identity work (Sveningsson and Alvesson, 
2003; Watson, 2008; Down and Reveley, 2004), the interplay between individual and corporate identity, we see the interactive shaping of founder and firm.

\subsection{How corporate identity interacts with market identity}

When Peaceful Dinner began and created the market for meal kits in Sweden, the main challenge lie in creating awareness and understanding of what this product/service was and what it could become. Petra had to convince stakeholders of the potential of the idea: to facilitate family dinners and the convenience this would bring to everyday life. At Peaceful Dinner, they put a lot of time into developing arguments and designing working solutions to practical issues. Thus, in the beginning the market identity was created jointly with the corporate identity of Peaceful Dinner and Petra had a large influence over these interlinked processes. As more actors entered the market, they too wanted to influence the market identity by adding values, strategies and behaviours, increasing competition and changing the context. This is in line with marketing research demonstrating how all stakeholders involved will collectively influence how the market develops (Santos \& Eisenhardt, 2009). To Petra this was a threat; she worried that new market members might harm the market identity and the platform for doing business that she had been struggling to develop. "A lot of it feels so homemade - if you look at websites, processes, ways of working" (Petra). Turning to our other cases that came in later, they saw the relationship to the market as a collaborative achievement, almost assisting each other in creating awareness of the new idea, or as a competitive situation encouraging product development. In our cases it is clear how founders with previous experience from other types of businesses adjusted their business ideas to fit the meal-kit market. For example, Home-Grown, which was previously involved in the farmers market, focused on locally produced food.

The firms carefully kept an eye on other members on the market trying to adapt. Sometimes this meant copying products, ideas or even corporate values that appeared profitable, and sometimes this meant trying to do something different in order to create a niche or other advantage. The firms also actively engaged in seeking input from customers. Some did surveys and telephone interviews, while others set up more personal meetings such as focus groups and home visits. The feedback from customers on the market affected the firms' development and sometimes even challenged corporate identity. One example is when customers asked for meal kits adapted for children. At Peaceful Dinner, this was against the firm's corporate identity, which built on Petra's food philosophy, thinking that children should learn to eat the same food as adults. Eventually this caused the corporate identity to change in order to adapt to market trends. Petra described this as follows: "We are now releasing a meal kit for children, which we think will become one of our new major products. I have been a little reluctant about it in fact, knowing that there is no such thing as 'child food'. But nevertheless, it is the most common reason for customers to unsubscribe [...] We have to make an attractive meal kit; otherwise we won't sell." Thus, we saw how corporate and market identity interlinked in different ways.

\subsection{How individual identity interacts with market identity}

Thus far we have illustrated how identity interacts between the individual and the firm, as well as between the firm and the market. We also find interactions between individual identity and market identity (see Figure 1). As Petra created Peaceful Dinner, she simultaneously created the market and she based this interactive process on her personal ideas and values and her individual identity. She told us how she put a lot of effort into explaining what the meal-kit concept was all about. She was also active in the media, where she was usually portrayed as the founder of the meal kit. Hence, we can see that Petra's identity 
influenced the market identity, creating the cognitive reference that the other incoming members to the market had to comply with or try to cooperate with.

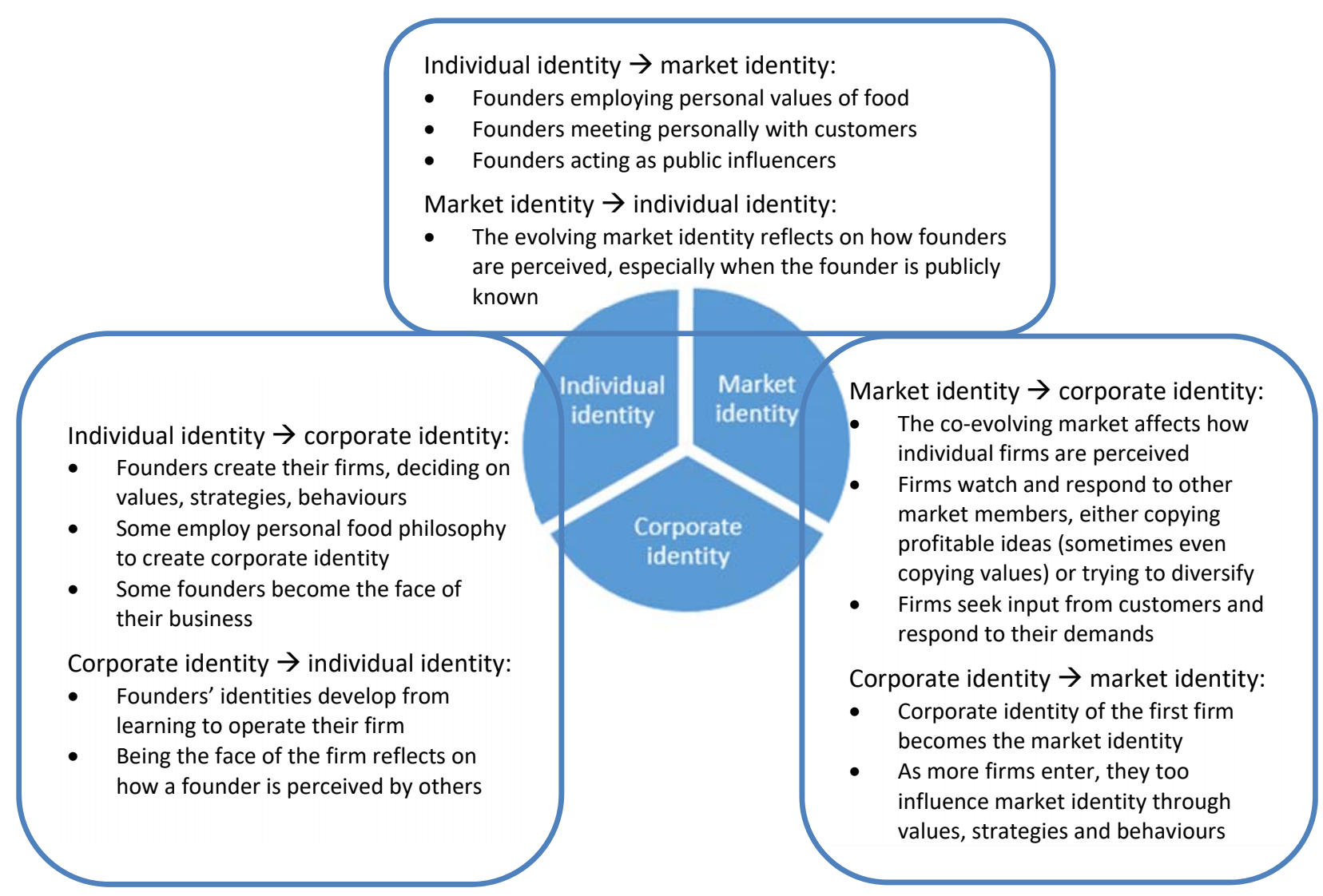

Figure 1. Interactions between individual identity, corporate identity and market identity.

Some of the in-flowing market members were passive and some more active when it came to making a footprint on the evolving market. Organic Dinner, for example, created a niche by focusing on almost fully organic meals. They used national celebrities in their marketing to build trust in their company, and their campaign also had an impact on the market. As the number of firms in the market grew, Petra experienced a loss of control over 'her concept', and as a food influencer, she kept influencing and pushing the developing market identity in the direction she preferred. Thus, being active in the meal-kit market as an individual means that you belong to a group of actors and a certain context. We have shown how individual identity influences market identity and how market identity can influence individual identity in an interactive process.

\subsection{Identities in a new developing market}

Our case studies have shown how the identity concept can explain different processes or functions in new market development. First, identity has a constructing function; identities can be used to construct and build firms and markets. Here, we differentiate between entrepreneurship built on individual identity and entrepreneurship built to fit with a market identity. The former concerns firms that are created from a founder's individual identity, building on his or her values and philosophies. An example of this is the way Petra used her individual identity to create both Peaceful Dinner and the meal-kit market, as such. The 
latter concerns founders who strive to become entrepreneurs, where they seek out and use a prevailing market identity to construct a firm (i.e. build their entrepreneurial process around an existing market identity). Examples of this are David and Emily seeking inspiration from the prevailing market identity as they created their businesses.

Second, identity has a guiding function, opening the space for new ideas and setting boundaries for what is possible within the market. We show how identity was the source of new ideas as the firms developed the new concept of meal kits. Identity also imposed boundaries for firms and individuals; for example, market identity causes firms and individuals to comply with this identity to become members, or corporate identities may affect what actions are possible. This guiding function is part of identity work. Here we would like to extend the claim made by Navis and Glynn (2010) that there is a challenge in navigating market identity and corporate identity. Handling contradicting identities is what Sveningsson and Alvesson (2003), Watson (2008), and Down and Reveley (2004) refer to as identity work. However, these scholars describe identity work merely as the formation of an individual identity, whereas we argue that identity work also relates to the formation of corporate identity and market identity. Thus, identity work may be a response to contradicting identities between different levels, and it may be undertaken by individuals as well as firms and markets. Thus, by imposing identity work, identity takes on a guiding function to enable navigation between identities on different levels.

Third, identity has a configuring function. We have illustrated how individual, corporate and market identities interact to shape entrepreneurs, firms and a new market. This is not a linear process where identity flows from the individual, to the firm, to the market. Instead, identity flows between contexts, back and forth (see Figure 1). This is in line with Welter's (2011) two-way interaction between entrepreneurship and context. According to Pratt (2003 in Danes and Jang, 2013), identity has two dimensions: one individual and one social. Our findings extend this reasoning to include corporate and market identity. Hence, just as an individual's identity is connected to a person's sense of belonging to social groups (Fauchart and Gruber, 2011), corporate identity and market identity are likewise connected to social groups that together constitute a frame of reference. The founder, the firm and the market are thereby part of the same context. Thus, identity has a configuring function, taking part in shaping contexts.

\section{Conclusions}

In this paper, we have focused on identity as a process and explored the role of identity in entrepreneurship by following the marketing practices and development of five start-ups in a new market. We focused on three different contexts: individual identity, corporate identity and market identity, as we wanted to develop knowledge about the dynamics between entrepreneur, firm and market.

The firms in our study were all in a formative phase and the lack of existing structures and expectations in what was to become the 'meal-kit market' made the cases sensitive to change, but also open for signals between the people involved. By focusing on identity as a process, it was possible to follow the interplay between entrepreneurs, firms and the market as well as to highlight three functions of identity. First, identity has a constructing function, giving structure and assisting in developing a new firm and market. Existing identities were used as role models or building blocks in the construction of new firms and markets. Secondly, identity has a guiding function, involved in navigating and balancing identities by imposing identity work in founders, firms and markets. Our findings show the challenges involved in this navigation: identities opened the space for new ideas but also placed limitations on what is possible. Thirdly, identity has a configurating function, taking part in shaping contexts and vice versa. We illustrate 
how identities evolve as they are negotiated in interaction with context. We saw how identity changed with time - how an existing identity was shaped by another identity and almost instantly re-shaped into a new identity. This study thus illustrate how identities give direction to the entrepreneurial processes during the development of new founders, new firms and new markets. We argue that the identity work conducted between levels is one of the main mechanisms shaping entrepreneurial processes.

\section{Contributions and implications}

There is a rich body of literature on the development of established firms and markets. However, we know less about the development of start-ups in new markets. This paper combines ideas within marketing and entrepreneurship to provide novel ideas on how the identities of individuals, firms and markets interact to create new firms and new markets. Thus, the paper contributes by showing 1) how identities develop in founders, firms and the market, and 2) how interactions between these three levels of identities affect the development of each. This stresses that the development of identities could be added to the explicit tasks of a founder. This applies to the development of the founder's individual identity, as well as to the identity of the firm and the market. Hence, this paper advances knowledge on the dynamics between entrepreneurs, firms and the market and provides further elucidation on the functions held by identity.

From this, we may draw some practical implications for founders and executive managers. First, this paper sheds light on the importance of addressing the influence that individual identities as well as a market identity may impose on a firm's identity work. Our intent is to help founders and managers master the challenges in navigating between these different identities. Secondly, our findings have implications for founders and managers on a personal level, demonstrating that they need to be aware of how individual identities become linked to the firm and market. Founders' creations may eventually move beyond their control, yet continuously affect them as individuals. Of course, it is important to note that these bonds bring not only challenges, but also opportunities for both founders and firms. The challenge lies in navigating between the different identities. In order to provide guidance (inspired by the work of both Hatch and Schultz (2001) and Balmer (2008)), we have provided a set of critical questions which are listed in Figure 2. These questions aim to assist founders and managers in understanding and managing identityrelated concerns.

For researchers, identity is proposed as a useful lens to study the interplay between entrepreneurship and context. This paper contributes by illustrating how the concept of identity can be used to discuss the interaction between entrepreneurship and context; more specifically, how different levels of identity interact in developing firms and markets. By using identity to explore this interaction, we also bring up the problematic notion of downgrading the entrepreneur in the ongoing context debate. We argue that, while the individual and his or her identity should not be neglected in discussions about the entrepreneurial process, entrepreneurship should also not be treated as an individualized phenomenon. To us, the boundary between the individual and context is fluid and vague rather than certain. Thus, identity should be viewed as a useful lens to study the interplay between entrepreneurship and context. 


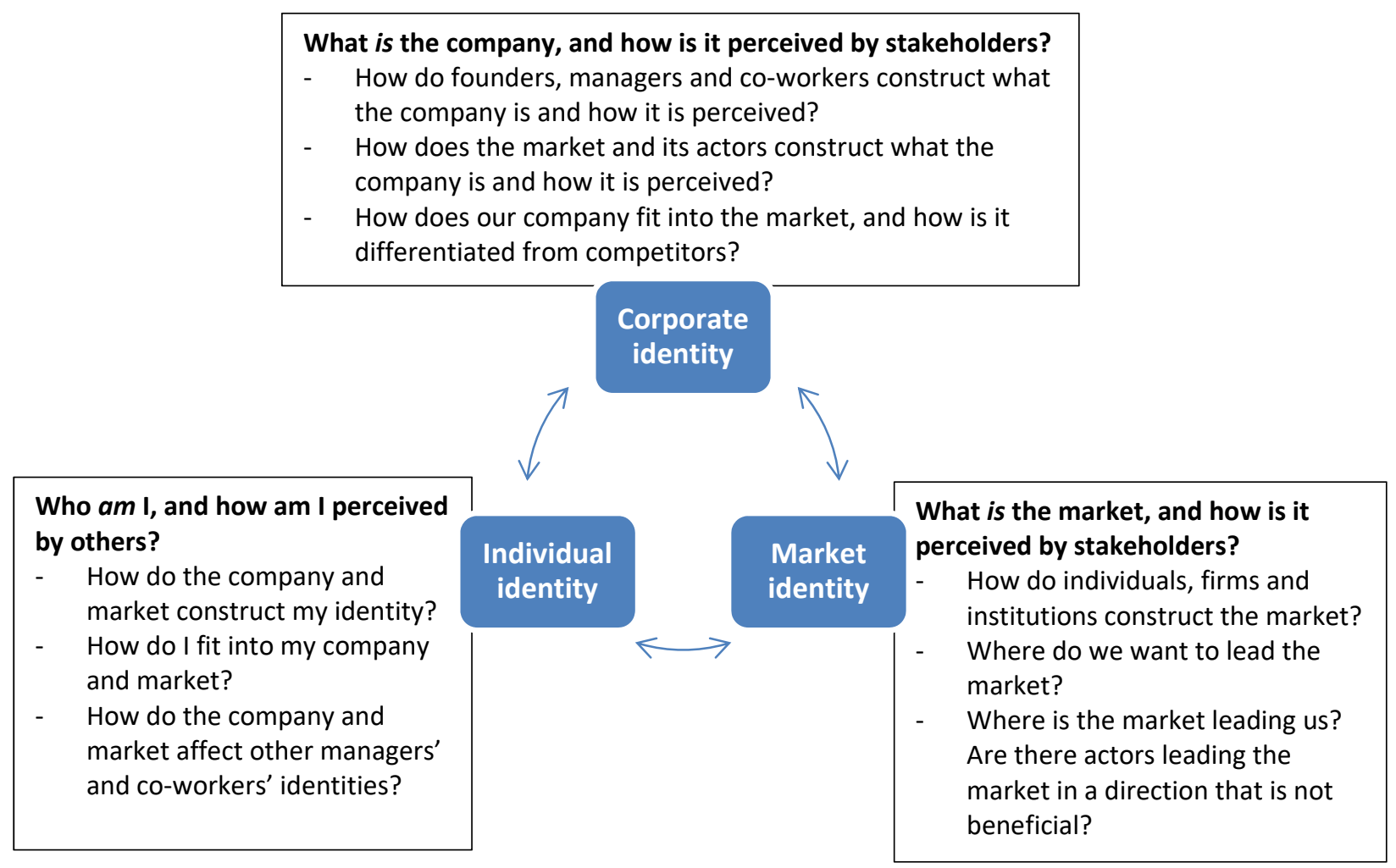

Figure 2. Identity interacts between contexts. The textboxes provide critical questions for founders and managers to address.

\section{References}

Abimbola, T. (2001). Branding as a competitive strategy for demand management in SMEs: an exploratory study. Journal of Research in Marketing and Entrepreneurship, Vol. 3, Iss. 2, pp. 97-106.

Abimbola, T., \& Kocak, A. (2007). Brand, organization identity and reputation: SMEs as expressive organizations: A resources-based perspective. Qualitative Market Research: An International Journal, 10(4), 416-430.

Abimbola, T. and Vallaster, C. (2007). Brand, organisational identity and reputation in SMEs: an overview. Qualitative Market Research: An International Journal, Vol. 10, Iss: 4, pp. 314-348.

Abratt, R., \& Kleyn, N. (2012). Corporate identity, corporate branding and corporate reputations: Reconciliation and integration. European Journal of Marketing, 46(7/8), 1048-1063.

Ahonen, M. (2008). Branding-does it even exist among SMEs. In Proceedings of the 16th Nordic Conference on Small Business Research (Vol. 202).

Alvesson, M. (2003). Beyond neopositivists, romantics, and localists: A reflexive approach to interviews in organisational research. Academy of management review, 28(1), 13-33.

Alvesson, M., and Deetz, S. (2000). Doing critical management research. Sage.

Alvesson, M., and Kärreman, D. (2001). Odd couple: making sense of the curious concept of knowledge management. Journal of management studies, 38(7), 995-1018.

Anderson, A. R., Jack, S. L., and Dodd, S. D. (2005). The role of family members in entrepreneurial networks: Beyond the boundaries of the family firm. Family Business Review, 18(2), 135-154. 
Balmer, J. M., and Gray, E. R. (2003). Corporate brands: what are they? What of them?. European Journal of Marketing, 37(7/8), 972-997.

Balmer, J. M. (2008). Identity based views of the corporation: Insights from corporate identity, organisational identity, social identity, visual identity, corporate brand identity and corporate image. European Journal of Marketing, 42(9/10), 879-906.

Blombäck, A., and Brunninge, O. (2009). Corporate identity manifested through historical references. Corporate Communications: An International Journal, 14(4), 404-419.

Boettke, P. J., and Coyne, C. J. (2009). Context matters: Institutions and entrepreneurship. Now Publishers Inc.

Boyle, E. (2003). A study of entrepreneurial brand building in the manufacturing sector in the UK. Journal of Product and Brand Management, Vol. 12, No: 2, pp. 79-93.

Bresciani, S. and Eppler, M., J. (2010). Brand new ventures? Insights on start-ups' branding practices. Journal of Product and Brand Management, Vol. 19, Iss: 5, pp. 356-366.

Bruderl, J., and Schussler, R. (1990). Organisational mortality: The liabilities of newness and adolescence. Administrative Science Quarterly, 530-547.

Bygrave, W. D., and Hofer, C. W. (1991). Theorizing about entrepreneurship. Entrepreneurship theory and Practice, 16 (2), 13-22.

Chappelli, P. and Sherer, P.D. (1991). The missing role of context in OB: the need for a meso-level approach. Research in Organisational Behavior, Vol. 13, pp. 55-110.

Cornelissen, J. P., Haslam, S. A., and Balmer, J. M. (2007). Social identity, organizational identity and corporate identity: Towards an integrated understanding of processes, patternings and products. British Journal of Management, 18(1), 1-16.

Czarniawska, B. (2007). Shadowing and other techniques for doing fieldwork in modern societies. Liber AB, Korotan Ljublijana, Slovenia.

Danes, S. M., and Jang, J. (2013). Copreneurial identity development during new venture creation. Journal of Family Business Management, 3(1), 45-61.

Dodd, S. D., and Anderson, A. R. (2007). Mumpsimus and the mything of the individualistic entrepreneur. International Small Business Journal, 25(4), 341-360.

Down, S., and Reveley, J. (2004). Generational encounters and the social formation of entrepreneurial identity:'Young guns' and 'old farts'. Organization, 11(2), 233-250.

Eisenhardt, K. M. (1989). Building theories from case study research. Academy of management review, 14(4), 532-550.

Fauchart, E., and Gruber, M. (2011). Darwinians, communitarians, and missionaries: The role of founder identity in entrepreneurship. Academy of management journal, 54(5), 935-957.

Fletcher, D. (2003). Framing organizational emergence: discourse, identity and relationship. New movements in entrepreneurship, 125-142.

Fletcher, D. (2007). 'Toy Story': The narrative world of entrepreneurship and the creation of interpretive communities. Journal of Business Venturing, 22(5), 649-672.

Freeman, J., Carroll, G. R., and Hannan, M. T. (1983). The liability of newness: Age dependence in organisational death rates. American sociological review, 692-710.

Gaddefors, J., and Anderson, A. R. (2017). Entrepreneursheep and context: when entrepreneurship is greater than entrepreneurs. International journal of entrepreneurial behavior and research, 23(2), 267278.

Gaddefors, J., and Anderson, A. R. (2009). Market creation: the epitome of entrepreneurial marketing practices. Journal of Research in Marketing and Entrepreneurship, 10(1), 19-39.

Gaddefors, J. (2005). Creating context-entrepreneurial opportunities in a consumer market setting. Journal of Enterprising Culture, 13(03), 199-224. 
Gioia, D. A., Schultz, M., \& Corley, K. G. (2000). Organizational identity, image, and adaptive instability. Academy of management Review, 25(1), 63-81.

Glaser, B. G. (1978). Theorethical sensitivity. Sociology Press.

Glaser, B. G., and Strauss, A. (1967). The discovery of grounded theory: Strategies for qualitative research. Aldine de Gruyter, New York.

Hatch, M. J. and Schultz, M. (2001). Are the strategic stars aligned for your corporate brand? Harvard Business Review, February 2001, pp. 128-134.

Jensen, M. (2010). Legitimizing illegitimacy: How creating market identity legitimizes illegitimate products. Research in the Sociology of Organisations, 31, 39-80.

Korsgaard, S., Ferguson, R., and Gaddefors, J. (2015a). The best of both worlds: how rural entrepreneurs use placial embeddedness and strategic networks to create opportunities. Entrepreneurship and Regional Development, 1-25.

Lindgren, M. and Packendorff, J. (2009). Social constructionism and entrepreneurship - basic assumptions and consequences for theory and research. International Journal of Entrepreneurial Behavior and Research, Vol. 15, No. 1, pp. 25-47.

Lindgren, M., and Wåhlin, N. (2001). Identity construction among boundary-crossing individuals. Scandinavian Journal of Management, 17(3), 357-377.

Markwick, N., \& Fill, C. (1997). Towards a framework for managing corporate identity. European Journal of marketing, 31(5/6), 396-409.

Maurya, U. K., Mishra, P., Anand, S., \& Kumar, N. (2015). Corporate identity, customer orientation and performance of SMEs: Exploring the linkages. IIMB Management review, 27(3), 159-174.

Melewar, T. C., and Karaosmanoglu, E. (2006). Seven dimensions of corporate identity: A categorisation from the practitioners' perspectives. European Journal of Marketing, 40(7/8), 846-869.

Morrow, S. L. (2005). Quality and trustworthiness in qualitative research in counseling psychology. Journal of counseling psychology, 52(2), 250-260.

Navis, C., and Glynn, M. A. (2010). How new market categories emerge: Temporal dynamics of legitimacy, identity, and entrepreneurship in satellite radio, 1990-2005. Administrative Science Quarterly, 55(3), 439-471.

Penrose, E. T. (1995). Theory of the growth of the firm, $3^{\text {rd }}$ ed., Oxford, Basil Blackwell.

Petkova, A. and Rindova, V. (2008). How can new ventures build reputation? An exploratory study. Corporate Reputation Review, Vol. 11, Iss: 4, pp. 320-334.

Rindova, V. P., Petkova, A. P., and Kotha, S. (2007). Standing out: how new firms in emerging markets build reputation. Strategic Organisation, 5(1), 31-70.

Rode, V. and Vallaster, C. (2005). Corporate branding for start-ups: The crucial role of entrepreneurs. Corporate Reputation Review, Vol. 8, No: 2, pp. 121-135.

Sandberg, J., and Alvesson, M. (2011). Ways of constructing research questions: gap-spotting or problematization?. Organisation, 18(1), 23-44.

Santos, F. M., and Eisenhardt, K. M. (2009). Constructing markets and shaping boundaries: Entrepreneurial power in nascent fields. Academy of Management Journal, 52(4), 643-671.

Shane, S., and Venkataraman, S. (2000). The promise of entrepreneurship as a field of research. Academy of management review, 25 (1), 217-226.

Silverman, D. (1993). Interpreting qualitative data: methods for analysing qualitative data.

Singh, J. V., Tucker, D. J., and House, R. J. (1986). Organisational legitimacy and the liability of newness. Administrative science quarterly, 171-193.

Steier, L. (2001). Next-generation entrepreneurs and succession: An exploratory study of modes and means of managing social capital. Family Business Review, 14(3), 259-276.

Steier, L. (2007). New venture creation and organisation: A familial sub-narrative. Journal of Business Research, 60(10), 1099-1107. 
Stinchcombe, A. L. (1965). Social structure and organisations. Pp. 153-93 in J. G. March (ed.), Handbook of Organisations. Chicago: Rand McNally.

Sveningsson, S., and Alvesson, M. (2003). Managing managerial identities: Organisational fragmentation, discourse and identity struggle. Human relations, 56(10), 1163-1193.

Van Riel, C. B., \& Balmer, J. M. (1997). Corporate identity: the concept, its measurement and management. European journal of marketing, 31(5/6), 340-355.

Vargo, S. L., \& Lusch, R. F. (2004). Evolving to a new dominant logic for marketing. Journal of marketing, 68(1), 1-17.

Vargo, S. L., \& Lusch, R. F. (2016). Institutions and axioms: an extension and update of service-dominant logic. Journal of the Academy of marketing Science, 44(1), 5-23.

Watson, T. J. (2008). Managing identity: Identity work, personal predicaments and structural circumstances. Organisation, 15(1), 121-143.

Watson, T. J. (2013). Entrepreneurship in action: bringing together the individual, organizational and institutional dimensions of entrepreneurial action. Entrepreneurship \& Regional Development, 25(56), 404-422.

Welter, F. (2011). Contextualizing entrepreneurship - conceptual challenges and ways forward. Entrepreneurship Theory and Practice, Vol. 35, Iss. 1, pp. 165-184.

Whetten, D. A. (2006). Albert and Whetten revisited: Strengthening the concept of organisational identity. Journal of Management Inquiry, 15(3), 219-234.

Whetten, D. A., and Mackey, A. (2002). A social actor conception of organisational identity and its implications for the study of organisational reputation. Business and Society, 41(4), 393-414.

Witt, P. and Rode, V. (2005). Corporate brand building in start-ups. Journal of Enterprising Culture, Vol. 13, Iss: 3, pp. 273-294. 